\title{
Political Polarization and Selective Exposure of Social Media Users in Indonesia
}

\author{
Denny Januar Ali ${ }^{1}$, Eriyanto ${ }^{2}$ \\ ${ }^{1}$ Indonesian Survey Circle (email: dennyali46@yahoo.com) \\ ${ }^{2}$ Department of Communication Science, Faculty of Social and Political Sciences, Universitas Indonesia \\ (email: eriyanto09@ui.ac.id)
}

\begin{abstract}
This study is intended to answer the question of how political polarization is related to social media users' posts about Covid-19. The researchers chose health cases related to Covid-19 instead of political issues (e.g. elections) to prove that this political polarization has spread to many areas. The research also wants to see the relationship between this political polarization and selective exposure. Theories applied in this study are polarization, filter bubble, and selective exposure. The study applied two methods: social media network analysis and content analysis. The network analysis included 82,156 posts, while the content analysis was carried out on 4,050 social media accounts. The research outcome proves the occurrence of political polarization. Social media users were divided into two major groups, namely pro-Jokowi and anti-Jokowi. Each group interacted with fellow users who had the same political choices and shared the same message content. Users with certain political choices tend to receive the same information as their political choices, and ignore information from other political parties. Another interesting finding from this study is how this polarization was sharpened by the use of hashtags. Each party (supporters and oppositions of Jokowi) uses hashtags to create solidarity and mobilization from each supporter. Research also proves the validity of the selective exposure and filter bubble hypothesis in the Indonesian context.
\end{abstract}

Keywords:

political polarization; filter bubbles; selective exposure; social media; Covid-19

\section{Introduction}

The first instance of Covid-19 was reported on November 17th, 2019, in Wuhan, China. In early 2020, this virus then spread rapidly throughout the world. The phenomenon that occurred during this Covid-19 pandemic and not for the cases of previous viruses (SARS, H1N1 flu, Ebola, and $\mathrm{Zika)}$ is the emergence of conversations about this disease from people on social media. During the previous virus cases, information was generally centered on the government. Meanwhile, for Covid-19, the public takes part in discussions on social media. Various things are commented on by social media users, ranging from viruses and government policies to the government's way of handling the virus.
The era of social media is marked by the rise of digital opinion (Barisione, et.al, 2017; Barisione \& Ceron, 2017). Digital opinion is an activity carried out by citizens in the digital world in the form of comments or posts on social media. People's opinions are generally spontaneous and disorganized. Social media users express their opinions on the various events they follow in the media. The people's opinions on social media are generally homogeneous, whether they support or criticize an issue or policy. Social media users spontaneously express their opinions or commend or criticize certain policies. The form of this digital opinion is very diverse and usually carried out daily by social media users, 
such as posting, creating memes, commenting on the fellow users' opinion on an issue, and so on.

This digital opinion also occurs in the Covid-19 cases in Indonesia. Since the virus was first reported in November 2019, various comments have appeared on social media. This digital opinion is getting larger after the government announced the first positive case on March 2, 2020. Every day, various posts appear on social media. Users apply hashtags to attract the attention of other social media users. Each time the government makes a policy, a variety of comments and posts on social media emerge either in support of the policy or against it.

One important phenomenon associated with social media conversations about Covid-19 in Indonesia is the occurrence of political polarization. Every policy made by the government is followed by support from groups that are pro Joko Widodo (Jokowi) and criticism from groups that are against Jokowi. Whatever actions of the Jokowi government are, the proJokowi groups always support such actions and otherwise the contra-Jokowi groups always see the actions as negative and do not support the decisions.

This paper argues that the polarization which occurs in Indonesian politics cannot be separated from the presence of the internet and social media. The internet and social media increasingly occupy important positions in Indonesian politics. Social media enables audiences to get information which suits their needs, including political attitudes and choices. People with certain political choices can find information that suits their political choices. This hypothesis is often referred to as selective exposure. Selective exposure will ultimately sharpen the political polarization because people tend to only look for appropriate information and ignore information which is not appropriate. The study wants to examine the relationship between selective exposure theory and political polarization in the Indonesian political context. This kind of study has never been carried out in Indonesia. Similar studies have been conducted in other countries, e.g. studies by Bennet and Iyengar (2008); Iyengar and Hahn (2009); Dylko (et. al., 2017); Stroud (2008, 2010); Bozdag and Hoven (2015) and Kull (et.al, 2004).

There are two questions to be answered in this study. First, it describes political polarization in social media conversations on Covid-19. The thesis to be supported in this paper is that political polarization in Indonesia goes deep, where issues related to the health sector have political polarization. Second, this paper will explain causes of polarization on social media. Polarization occurs because people tend to get information from one side due to social media algorithms, which limit individuals.

\section{Literature Review \\ Political Polarization}

Political polarization refers to grouping people who share the same ideas or concepts (Bishop, 2008). Bishop described a number of characteristics of the political polarization. First, differences between members of the political community are accompanied by groupings of homogeneous people. Second, people with the same political choices gather in one group, and tend not to recognize other groups. Third, these differences are often difficult to put together because political choices are seen not only as winning or losing but also as a life choice. This makes it difficult to put the groups together. Political polarization is often associated with political tribalism (Maffesoli, 2016). According to Maffesoli, we lived in conditions where tribalism ruled, i.e. the emergence of groups where such groups were distinguished by their similar lifestyle and tastes.

The phenomenon of political polarization occurs simultaneously with high access to 
information, especially the presence of social media (Sphor, 2017). A number of studies show the relationship between polarization and information access. People/voters with different political orientations tend to choose different media. Fragmented media are based on political choices. For example, the study by Iyengar and Hahn (2009) shows liberals in America (Democratic voters) tend to watch $\mathrm{CNN}$ and NPR news outlets, whereas conservatives (Republican voters) tend to watch Fox News. Kull's (et.al, 2004) research on the Gulf War made similar findings. Television viewers, who believe that there are weapons of mass destruction in Iraq, tend to watch Fox, while those who don't believe watch CNN or PBS.

How to explain the link between information access and political polarization? According to Sphor (2017), there were two explanations. First is the social media algorithm. An important characteristic of social media is message customization, where users can choose the message that best suits their needs. Social media then builds algorithms for message customization to make it easier for users. The impact of this algorithm is users only relate to information and friends that suit their needs and political interests. Pariser (2012) referred to this algorithm as a filter bubble. Users live in a space which contains similar people and information.

Second is selective exposure. Social media and the internet gives the audience a lot of information. Such a huge amount of information makes people become confused and feel uncomfortable, because the information is different from each other and contradicts each other. In order to manage such confusion and discomfort, the individuals then choose the most appropriate information to their political choices (Bennet \& Iyengar, 2008; Iyengar \& Hahn, 2009). This information selection strengthens the political polarization because individuals tend to only choose and trust information in accordance with their political choices.

\section{Filter Bubble}

Pariser (2012) made popular the term "filter bubble" to describe how the polarization was created and reinforced by social media. Social media targets audiences to small segments and directs them according to the interests and proclivities of each user. One of the techniques frequently used is the recommendation system (Pariser, 2012). The internet search history by users is recorded and by certain algorithms internet users are directed to certain pages according to their search history. The recommendation system has previously been predicted by Negroponte (1995). According to Negroponte (1995), the internet was a decentralized media. Users just choose and search for useful information and ignore other information which is deemed irrelevant.

Social media algorithms work subtly, so users are not aware that the choice of information and friends for them is recommended by social media. A study conducted by Rader and Gray (2015) shows that Facebook users are not aware of the recommendations provided by the Facebook homepage. Their study found that the users were unaware because the information recommended by the social media (Facebook) was indeed the information which was sought and did not conflict with their political beliefs or choices.

A number of studies have found different outcomes regarding the extent to which filter bubbles affect political polarization. A study conducted by Borgesius (et.al, 2016) shows that social media algorithms do not affect individual selection. Although social media helps individuals to direct information, social media users can decide on the information which is different from what is recommended by social media. However, the outcomes of studies by Dylko (et. al, 2017) and Rosyadi and Eriyanto (2019) show the influence of the social media algorithm system. According to such two studies, the filter bubble has influence because 
the system works in a subtle way. Therefore, the users do not realize the system. The users follow what is recommended by social media because the recommended information does not conflict with their political beliefs and choices.

\section{Selective Exposure}

The concept of selective exposure originates from the cognitive dissonance theory introduced by Leon Festinger. According to Festinger (quoted from West \& Turner, 2018), people always avoided dissonance. Dissonance is a condition or situation where there is a difference or conflict between one attitude and another, or between behaviour and attitude. The situation causes inconvenience or discomfort for a person psychologically. Such people will try to reduce or even eliminate that discomfort. One of the selective exposure initiatives is looking for information to reduce inequality in attitude and behaviour. People will also selectively choose and search for information which can support their attitudes or beliefs.

This selective exposure theory has not been used for a long time, and even tends to be forgotten (Stroud, 2008). The phenomenon of the internet and the birth of political polarization have made this theory relevant again (Stroud, 2008, 2010). Bennet and Iyengar (2008) used the selective exposure concept in politics. They introduced a concept which is referred to as partisan selectivity. The principle of this concept is that a person tends to choose news which agrees with his political attitudes and preferences. News is used as a medium to strengthen the attitude and look for a justification of the attitude and perspective of a person.

The emergence of selective exposure, according to Bennet and Iyengar (2008), could not be separated from the context of the birth of the internet. The media, which is very diverse and segmented (into groups and political choices), gives citizens an alternative in choosing the media. This condition occurs when the voters simply choose media which can support their political views and ignore other media which have an opposite attitude with their political views (Bennet \& Iyengar, 2008; Frey, 1986).

Numerous studies show strong evidence for an association between political polarization and selective exposure. A study by Bakshy (et.al, 2015) on Facebook users shows that the choice of information and friends on social media is determined by the selective-exposure choice. Users prefer information which suits their political views and choices. Kull's (2004) study of the Iraq war also shows selective exposure. The audiences who believe in the existence of weapons of mass destruction in Iraq tend to choose the media which preach the existence of those weapons. On the contrary, the audience ignores media which preach the opposite.

\section{Bubble Filter, Selective Exposure, and Political Polarization}

A number of experts strictly separate the social media algorithm (filter bubble) and selective exposure (Sphor, 2017). For example, a study conducted by Dylko (et. al., 2017) sought to determine which factor is more influential in polarizing; social media algorithm or selective exposure. In contrast to Dylko (et. al, 2017), this study has an underlying assumption that selective exposure with social media algorithms (filter bubbles) cannot be separated from one another. The social media algorithm works based on selective exposure.

A number of studies show distorting boundaries between social media algorithms (filter bubbles) and selective exposure. A study conducted by Gil de Zuniga (et.al, 2017) found that social media users perceive they are always connected to events or information, even though they are not actively looking for news. Social media makes enormous information channels. People can receive any 
information from any source effortlessly. The information search process takes place passively, where users are given information which has been provided by social media. Other findings were presented by Sphor (2017) on availability bias. The social media algorithm works based on the compatibility with what we want. The system will display content that is deemed to be preferred by the users. Content displayed on social media pages will pass all information from a different perspective. The information provided (after being filtered by the algorithm) will be easier to process due to the availability bias.

Filter bubbles and selective exposure will strengthen political polarization. The social media algorithm with its optimal abilities selects information to be presented to the users and will further enrich the polarization of the community, because it reinforces the opinions and political views of each group. Each faction tends to reject a different perspective, even if it makes sense or is objective. News which agrees with the way of thinking can influence the polarization of the social media users' political views (Rosyadi \& Eriyanto, 2019). According to Spohr (2017), the consequence of filter bubbles and selective exposure is the loss of diversity. The community lives in a uniform world and is confronted with other people who have different views. This polarization occurs because the user sustains (self-perpetuating) and creates reinforcement (self-reinforcing) by selecting fitting information and negating information which does not support his view. The user is likely to receive appropriate information and reject to exchange ideas with groups which have different view (Bozdag \& Hoven, 2015).

\section{Methods}

To address the research's purpose (describing the polarization and causes of political polarization on social media), the researcher examined a social media conversation case about Covid-19. The researchers chose health cases (Covid-19) instead of political issues (e.g. elections) to prove that this political polarization has spread to many areas. Opposition between pro- and contra-Jokowi groups is extremely intense, and the two groups have different views even on healthrelated issues.

The time period chosen was six days of social media conversations about the Covid-19, since the first positive Covid-19 case was found, i.e. March 14-19, 2020. The first week was chosen because there was a debate about what should be done by the government during this week. By taking a sample of the social media users' (netizens) debates in the first week, it will illustrate what is being debated as well as test whether there is opinion polarization. Pro groups are likely to support what is done by Jokowi, while those who are against it will criticize Jokowi's policies.

To verify the polarization, this research refers to the advice given by Agarwal and Liu (2009). According to them there are three dominant approaches in looking at the polarization of a community, namely network, content, and hybridity approaches. The network approach focuses on the structure of the network to identify the people and relationships of each person in the network. The content approach assumes that members in a group tend to share the same information and discuss the same topic. Meanwhile, the hybridity approach is a combination of a network and content approach. This study applies a hybridity approach which combines the network and content analysis methods..

The social media which is the research subject is Twitter posts, because Twitter is a social media which has been carried out openly with data collection from third parties up until this research (see Hexmoor, 2015). For one week (March 14-19, 2020), there were hundreds of thousands of posts regarding Covid-19. To limit the number of conversations, the researcher 
used a hashtag. The researcher used the hashtag keyword to retrieve conversation data. Hashtag was used for finding groups and polarization. As stated by Bruns and Burgess (2012) and Yang (2016), the hash was important in the social media conversations because it played a role in creating imaginary communities. Through hashtags, millions of social media users can connect to talk about the same topic, even if they don't know each other. The researcher assumed that groups (pro and anti-Jokowi) built an imaginary community by recognizing members of the group through the hashtags used.

According to Marozzo and Besi (2017), hashtags can be used to identify polarization on social media. Social media users with different political orientations will use different hashtags to show their political orientation. Researchers chose conversations on social media for 6 days (March 14-19, 2020). This refers to the opinion of Barisione and Ceron (2017). According to them, the digital opinion movement on social media is temporal, lasting only a few days. During those six days, there were three hashtags (\#) for Covid-19, i.e. \#IndonesiaBersamaJokowi, \#IndonesiaButuh
Pemimpin and \#IndonesiaNeedLeader. The total number of posts (tweets) which use the hashtag IndonesiaBersamaJokowi for one week is 32,587 , \#IndonesiaButuhPemimpin is 23,296 , and \#IndonesiaNeedLeader is 26,273 . The total number of tweets from the three hashtags is 82,156 . All posts were included in this study. Hashtag \#IndonesiaButuhPemimpin is used by the pro-Jokowi group, while the hashtag \#IndonesiaButuhPemimpin and \#IndonesiaNeedLeader are used by anti-Jokowi groups.

To answer questions regarding political polarization, the Social Media Network Analysis method was applied (Barisione \& Cheron, 2017). The work process had two stages. First, social media conversations (crawling) of the three hashtags were retrieved. Data was collected by NodeXL software. Second, the data obtained was then visualized and analysed using Gephi software. The analysis was carried out at three levels: network structure, group (modularity), and actors (Golbeck, 2016). The structure level includes density, diameter (furthest distance among the actors [social media accounts] with other actors in a network), and distance (average distance of the

\section{Figure 1.}

Number of Tweets on Covid-19 between March 14-19, 2020

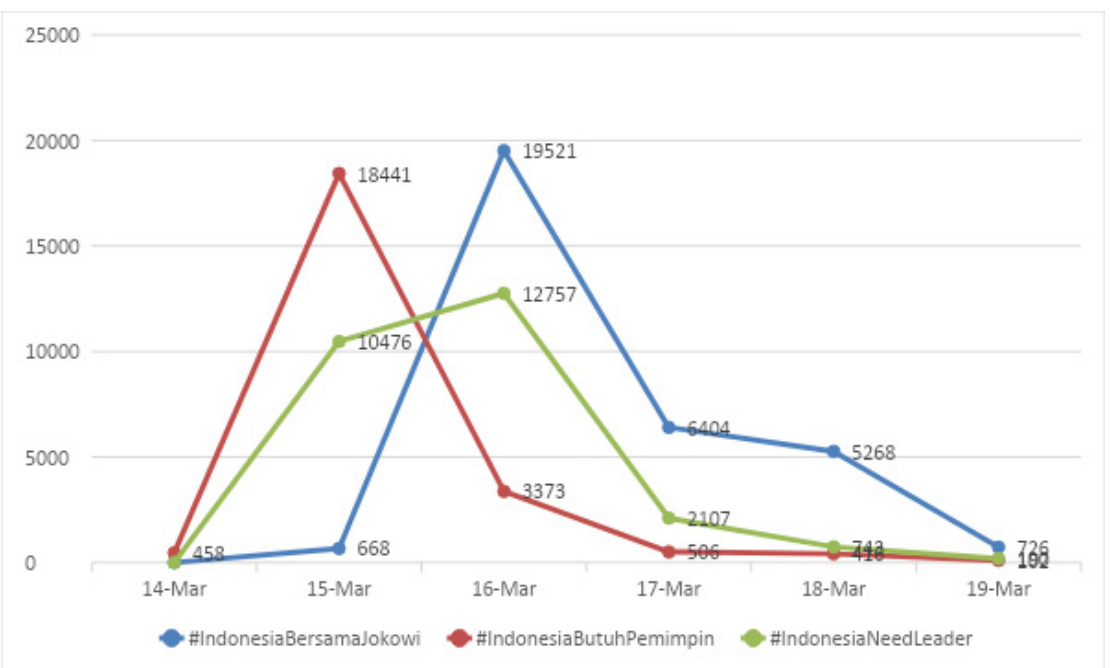

Source: Crawling data used NodeXL 
actors (media account) with other social media account. The group level looks at how many clusters (groupings) in the network, while the actor level identifies who the dominant actor (social media account) is, including popular actors (Degree Centrality), actors acting as a bridge (Betweenness Centrality), and actors closest to other actors (Closeness Centrality).

To answer research questions about the causes of polarization, a content analysis was used (Marozzo \& Bessi, 2017). The researcher alleged that polarization was caused by two interrelated factors. First is selective exposure. Social media users have a predisposition (previous political attitudes or choices), i.e. in this case pro-Jokowi or antiJokowi. The social media users selectively select information according to their political attitudes or choices. The researcher assumed that those who were pro-Jokowi would choose the hashtag \#IndonesiaBersamaJokowi, while those who were anti-Jokowi would choose the hashtag \#IndonesiaButuhPemimpin and \#IndonesiaNeedLeader. To test this hypothesis, the research was carried out as follows. Of the total social media accounts which were involved in conversations about Covid-19, a total of 4,050 accounts were taken randomly. To find out the political attitudes or choices of social media users, the researcher took a sample of user posts over the span of one week. Then, such posts were identified to know whether the user was a supporter of Jokowi, opposition of Jokowi or neutral (does not support or oppose). This data was then cross-tabulated with the user's posts related to Covid-19.

Second is the filter bubble. This research also tests whether there is a relationship between political polarization and social media algorithms (filter bubble). Polarization occurs because social media users live in a narrow space with people (social media users) who have the same political choice as themselves. Users are limited by algorithms, where social media tends to direct users with friends who have the same political choice. To test this hypothesis, the researcher calculated the text duplication level as carried out in the Barisione study (et.al, 2017). Text duplication is the degree of similarity of a post (tweet). Two Twitter posts from two social media users may be similar - for example, one user duplicates the post by changing a sentence or adding a specific word but the contents of the two posts are similar. To calculate the level of text duplication, the researcher used DiscoverText software.

This research was conducted independently by researchers, not funded by any institution.

\section{Results}

This research wants to describe the occurrence of the political polarization found on social media, especially with conversations about the Covid-19 pandemic. To address the purpose of this study, researchers used the Social Media Network Analysis method. This method can reveal whether the conversations are divided into different groups or not. Figure 2 shows a network visualization of 82,156 Twitter posts. From this picture, the users were divided into two major groups. The first group is people who agree with President Joko Widodo's measures and they use the hashtag \#IndonesiaBersamaJokowi. Other group are users who disagree with President Joko Widodo (Jokowi). They initially used the hashtag \#IndonesiaButuhPemimpin. Then they changed the hashtag to \#IndonesiaNeedLeader.

From this image, it can be seen that there is political polarization. Those who agree with Jokowi tend to guarantee relations with fellow users who have the same view. Conversely, those who disagree with Jokowi also tend to relate to fellow users of the same type. The results can be found in the network visualization where there are two major groups (pro and anti-Jokowi). Those who are pro with Jokowi said that the president 
has taken correct measures in handling the Covid-19 case. The Covid-19 case was assessed to have many dimensions. It is not only a disease but it can also affect the economic, social, and political sector. The supporters of Jokowi in social media consider that Jokowi has acted properly by taking cautious steps and preventing panic in the community, while the anti-Jokowi users consider Jokowi to be slow

\section{Figure 2.}

\section{Network Visualization of the Twitter Conversations on Covid-19}

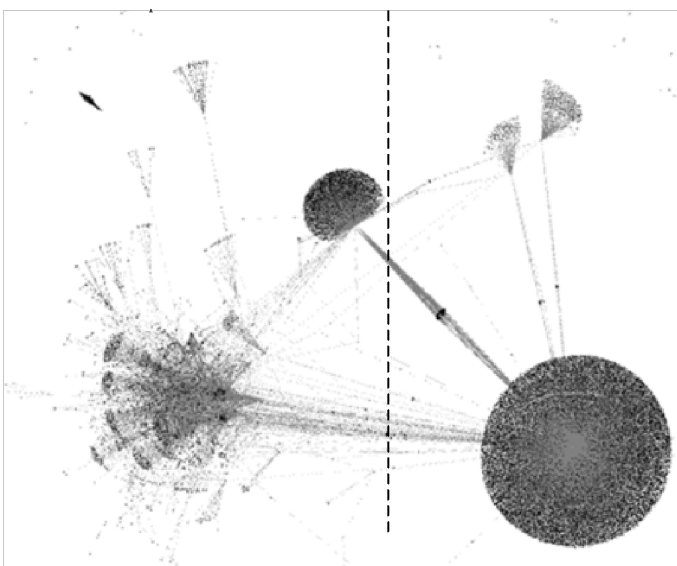

Note: $N=82,156$

Source: obtained from primary data in handling the Covid-19 issue. These users use the hashtags \#IndonesiaButuhPemimpin and \#IndonesiaNeedLeader to criticize Jokowi's leadership which is considered slow and indecisive. Jokowi is considered late in detecting the presence of this virus in Indonesia.

Table 1 shows a description of the user network structure of the pro-Jokowi (\#IndonesiaBersamaJokowi) and anti-Jokowi (using the hashtag \#IndonesiaButuhPemimpin and \#IndonesiaNeedLeader) groups. As Table 1 shows, both groups have similar network structure. The network density is relatively low (pro-Jokowi $=0.0002$; anti-Jokowi $=0.0003)$. This can be interpreted as users do not establish relationships with all social media users. The low density is followed by relatively high modularity (pro-Jokowi $=0.5$; anti-Jokowi $=0.4$ ). Although the network is divided into two large groups (pro and anti-Jokowi), each network group is divided into small clusters. The anti-Jokowi is distributed into higher number of clusters, i.e. 1,215 clusters, while the pro-Jokowi is segregated into small groups (clusters) in a lesser number, i.e. 194 clusters.

Other interesting data related to the network structure is the average distance.

Table 1.

Comparison of Network Structures

\begin{tabular}{lcc}
\hline \multicolumn{1}{c}{ Graph Metric } & $\begin{array}{c}\text { \#Indonesia } \\
\text { BersamaJokowi }\end{array}$ & $\begin{array}{c}\text { \#Indonesia } \\
\text { ButuhPemimpin and \#Indonesia } \\
\text { NeedLeader }\end{array}$ \\
\hline Vertices & 15772 & 15592 \\
Unique Edges & 22909 & 29249 \\
Edges With Duplicates & 9679 & 20321 \\
Total Edges & 32588 & 49570 \\
Self-Loops & 737 & 4193 \\
Connected Components & 161 & 1134 \\
Single-Vertex Connected Components & 116 & 1030 \\
Maximum Vertices in a Connected Component & 15496 & 14262 \\
Maximum Edges in a Connected Component & 31954 & 47811 \\
Maximum Geodesic Distance (Diameter) & 11 & 10 \\
Average Geodesic Distance & 2.9 & 3.1 \\
Graph Density & 0.000196743 & 0.000276468 \\
Modularity & 0.547345 & 0.414851 \\
Clusters & 194 & 1215 \\
\hline
\end{tabular}

Source: obtained from primary data 
Both network groups (pro and anti-Jokowi) have relatively short distances. The proJokowi group has an average distance of 2.9. This means that all network members can be reached in 2.9 steps. For the meantime, the anti-Jokowi network group has an average distance of 3.1. A short distance indicates the social media users are relatively connected to each other. Fellow social media users are only separated by about 3 steps. The farthest distance (diameter) is also relatively low (proJokowi $=11$, anti-Jokowi $=10)$. The farthest distance can be construed that any social media user can connect with the maximum farthest distance of 10 to 11 steps.

Apart from looking at the network structure and modularity, the hypothesis about political polarization can also be proven by identifying popular (dominant) actors for each hashtag. Are dominant actors the same or different? If the dominant actors are the same, it can be concluded that there is no polarization. On the contrary, if dominant actors are different, polarization occurs. This can be read that each group has its own dominant actor.

Figure 3 showsthenetwork visualization for the pro-Jokowi group (social media users using the hashtag \#IndonesiaBersamaJokowi). From this picture, it can be seen that there are 4 large clusters in the network and other smaller clusters. Total clusters in the pro-Jokowi social media conversation network are 194 clusters. Table 2 shows popular actors in the network. As this table shows, there are three active actors (social media accounts), i.e. @yusuf_ dumdum (degree =11,112), @blackpink828 (degree=1,781) and @cebongmilitan1 (degree $=1,781$ ) respectively. Posts of these three actors get responses from other accounts (in the form of retweets/replies/mentions) of more than 1,000 accounts. In fact, the @ yusuf_dumdum account's posts are retweeted more than 10 thousand times. A qualitative observation of the @yusuf_dumdum account shows that this account has been supporting Jokowi since the 2009 election. The hashtag \#IndonesiaBersamaJokowi was also created by this account. Then it was forwarded by other social media accounts which supported Jokowi. These three social media accounts are not only popular (marked by high degrees), but also have the highest levels of closeness, betweenness, and eigenvector compared to other social media accounts.

\section{Figure 3. \\ Network Visualization \\ of Twitter Conversations \#IndonesiaBersamaJokowi}

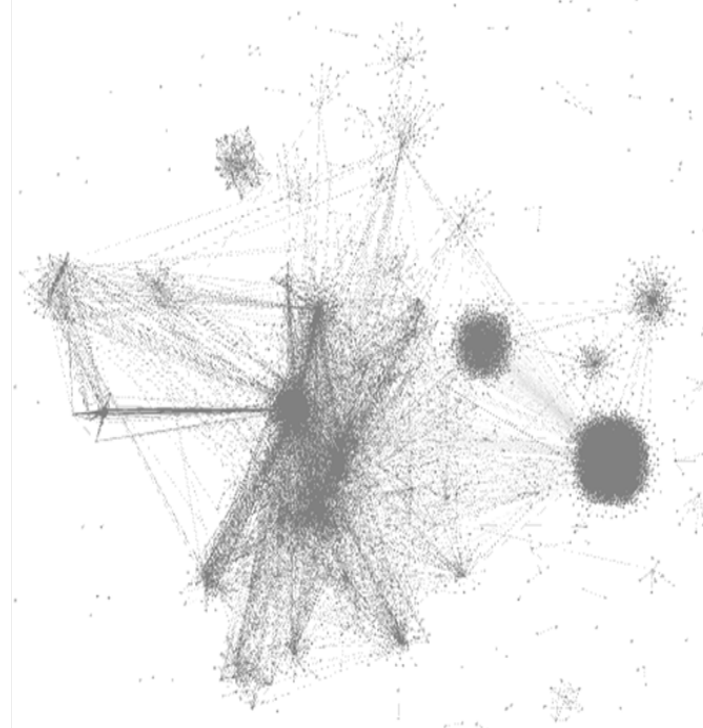

Note: $N=32,587$

Source: obtained from primary data

Figure 4 shows the network visualization of the anti-Jokowi social media users (using the hashtags \#IndonesiaButuhPemimpin and \#IndonesiaNeedLeader). The picture shows 7 large clusters and many other small clusters. In total there are 1,215 clusters in the network. Anti-Jokowi users use two hashtags. The initial hashtag used was \#IndonesiaButuhPemimpin. This hashtag became trending in Indonesia on March 14, 2020. This hashtag was once declining. In a number of Twitter conversations checked by 
Table 2.

Dominant Pro-Jokowi Actors (Social Media Accounts)

\begin{tabular}{lclclclc}
\hline \multicolumn{1}{c}{ Degree } & \multicolumn{2}{c}{ Betweenness } & \multicolumn{2}{c}{ Closeness } & \multicolumn{2}{c}{ Eigenventor } \\
\hline $\begin{array}{c}\text { Social Media } \\
\text { Account }\end{array}$ & Score & $\begin{array}{c}\text { Social Media } \\
\text { Account }\end{array}$ & Score & $\begin{array}{c}\text { Social Media } \\
\text { Account }\end{array}$ & Score & $\begin{array}{c}\text { Social Media } \\
\text { Account }\end{array}$ & Score \\
\hline yusuf_dumdum & 11112 & yusuf_dumdum & 12874620 & budi290180 & 3 & budi290180 & 1.000 \\
blackpink828 & 1781 & cebongmilitan1 & 11320104 & koko_fernanda & 3 & koko_fernanda & 1.000 \\
cebongmilitan1 & 1781 & jokowi & 4839681 & p_ysf & 3 & p_ysf & 1.000 \\
jokowi & 383 & blackpink828 & 3796342 & satria_wibawa & 3 & satria_wibawa & 1.000 \\
rizmawidiono & 335 & tambengbagong & 3333941 & shulwah & 3 & shulwah & 1.000 \\
yradianto & 320 & aniesbaswedan & 3223753 & khafidhmusdi & 3 & khafidhmusdi & 1.000 \\
rambahotheresia & 216 & yradianto & 3088789 & victor_tian17 & 3 & victor_tian17 & 1.000 \\
aryprasetyo85 & 194 & rambahotheresia & 2984965 & jheavenhome & 3 & jheavenhome & 1.000 \\
hanifah933 & 140 & rizmawidiono & 1992722 & plshn1 & 3 & plshn1 & 1.000 \\
pensiunanrambo & 138 & toffitorre781 & 1940550 & klarisaurelia & 3 & klarisaurelia & 1.000 \\
\hline
\end{tabular}

Source: obtained from primary data

the researcher, there had been some rumors that the hashtag was removed by Twitter. This group then replaced the hashtag with a new hashtag, \#IndonesiaNeedLeader. The new hashtag also once became trending on $15^{\text {th }}$ March 2020.

Figure 4.

Network Visualization of Twitter Conversations \#IndonesiaNeedLeaders and \#IndonesiaNeedLeader

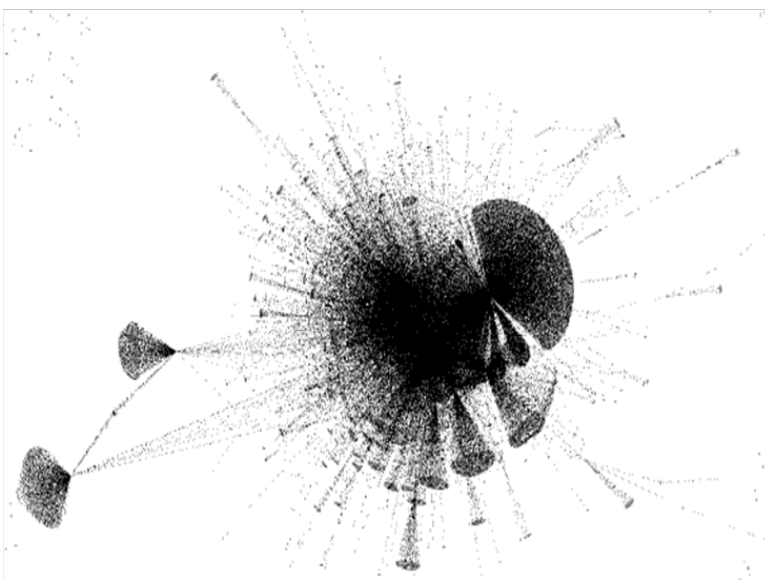

Note: $N=49,569$

Source: obtained from primary data

Figures 5 and 6 show the network visualization among the two hashtags. This image indicates there is a network image

similarity between the two hashtags. There are 6-7 large clusters, and then they split into hundreds of smaller clusters. This data shows that the social media accounts that use both hashtags are identical accounts (the same accounts).

Figure 5.

Network Visualization
of Twitter Conversations
IndonesiaButuhPemimpin

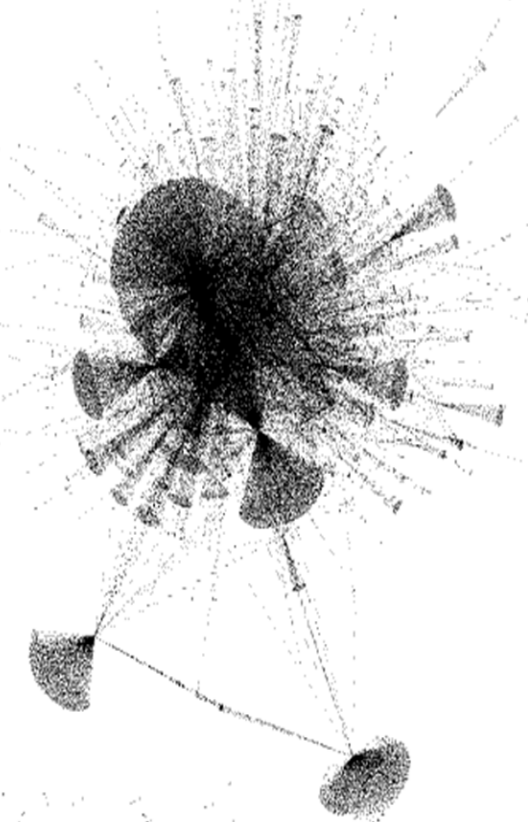

Note: $N=23,296$

Source: obtained from primary data 
Figure 6.

\section{Network Visualization of Twitter Conversations \#IndonesiaNeedLeader}

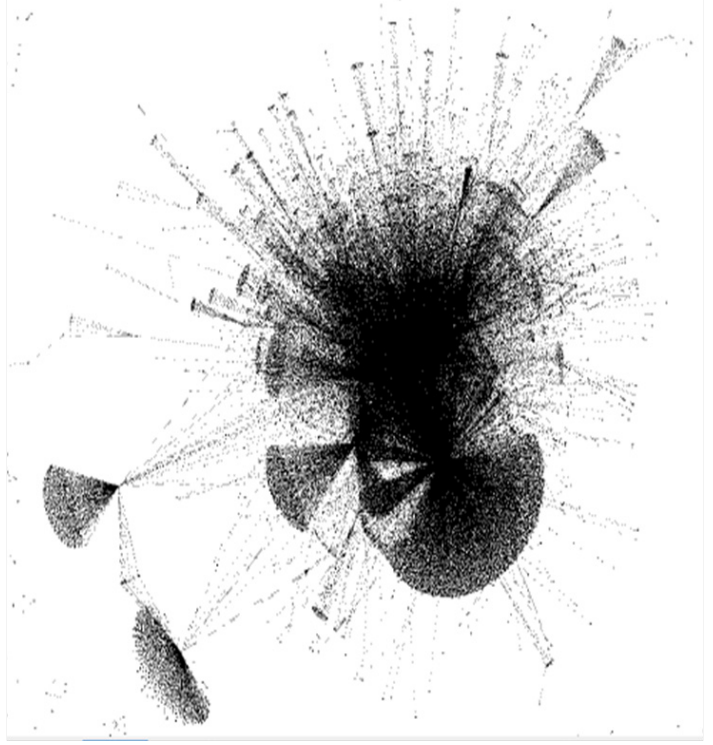

Note: $N=26,273$

Source: obtained from primary data

Table 3 shows the dominant actors (social media accounts) from the anti-Jokowi group. There are two dominant social media accounts, namely@msaid_didu and @liem_id. Both social media accounts have degrees above 1,000 . This means that posts from these social media accounts are retweeted by other social media users (in the form of retweets, replies, mentions and so on) for more than 1,000 times. For the account @msaid_didu, the number of degrees is even more than 7,000. This @msaid_didu account does not only have the highest degree, but also the best betweenness, closeness and eigenvector among other social media accounts. Qualitative observation of the @msaid_didu account shows that this account is indeed very active in the conversations related to the Covid-19. The two hashtags (\#IndonesiaButuhPemimpin and \#IndonesiaNeedLeader) were initially created by this account, which was then followed by other social media accounts.

What's interesting about this data is the account@aniesbaswedan (the official account of the Governor of Jakarta, Anies Baswedan), has higher degree (level), i.e. 1,362. Qualitative observation shows that the @ aniesbaswedan account does not make posts using the hashtag \#IndonesiaButuhPemimpin or \#IndonesiaNeedLeader. What happens is that many social media users who use the two hashtags include (mention) the @ aniesbaswedan account. They generally criticize Jokowi's policy and at the same time praise the policy taken by the Governor of DKI Jakarta. Among the anti-Jokowi groups, Anies Baswedan is one of the figures who is widely supported to run as a Presidential candidate in the 2024 election. Therefore, when they post criticisms to Jokowi, the users include praises for Anies Baswedan.

From the communication network data, it can be concluded that there is political polarization related to the social media users' conversations about Covid-19. Social media users are divided into pro and antiJokowi groups. This is proven in the network visualization where the network is divided into pro and anti-Jokowi groups. Users who are pro-Jokowi tend to establish relationships with those who support Jokowi, and vice versa.

The next question to be answered in this research is what causes political polarization in social media? To answer this question, there are two hypotheses. First, polarization occurs due to selective exposure. To test this hypothesis, a content analysis was carried out. Table 4 presents data on the relationship between the political choices of the social media users and the hashtags used. The political choices in this study were identified as supporting Jokowi, opposing Jokowi, and unclear (users/social media accounts cannot be identified as supporters or oppositions of Jokowi). As the table shows, the majority of Jokowi supporters $(70.5 \%)$ use the hashtag \#IndonesiaBersamaJokowi. Instead, the majority of socialmedia accounts opposing Jokowi (72.3\%) use the hashtag \#IndonesiaButuhPemimpin 
Table 3.

Dominant Anti-Jokowi Actors (Social Media Accounts)

\begin{tabular}{lcllllll}
\hline \multicolumn{1}{c}{ Degree } & \multicolumn{2}{c}{ Betweenness } & \multicolumn{2}{c}{ Closeness } & \multicolumn{2}{c}{ Eigenventor } \\
\hline Social Media Account & Score & $\begin{array}{c}\text { Social Media Ac- } \\
\text { count }\end{array}$ & Score & $\begin{array}{c}\text { Social Media } \\
\text { Account }\end{array}$ & Score & $\begin{array}{c}\text { Social Media } \\
\text { Account }\end{array}$ & Score \\
\hline msaid_didu & 7382 & msaid_didu & 75782322 & melztante & 3 & msaid_didu & 0.010 \\
liem_id & 1653 & visahabatmuslim & 8873426 & cindy48709529 & 3 & liem_id & 0.002 \\
aniesbaswedan & 1362 & liem_id & 8437784 & danangari_k & 3 & aniesbaswedan & 0.002 \\
visahabatmuslim & 665 & aniesbaswedan & 7232780 & ryanhabibi3 & 3 & irmanputrasidin & 0.001 \\
geloraco & 503 & b1d4d4r1_m03 & 5264044 & ysugiet & 3 & geloraco & 0.001 \\
irmanputrasidin & 471 & irmanputrasidin & 2498911 & bisenmulang & 3 & demosocrazy & 0.001 \\
b1d4d4r1_m03 & 402 & diezitoe & 1897270 & adam_lie & 3 & vaduka_kolak & 0.001 \\
hermana_t & 387 & geloraco & 1736330 & inayahrasyid & 3 & hermana_t & 0.000 \\
vaduka_kolak & 326 & vaduka_kolak & 1280129 & budi_sukses & 3 & tijabar & 0.000 \\
demosocrazy & 308 & _doncorleone_78 & 1169846 & gandawan & 3 & ajeng_cute16 & 0.000 \\
\hline
\end{tabular}

Source: obtained from primary data

Table 4.

Cross Tabulation of the Relationship between Political Choices and Hashtags Selected

\begin{tabular}{|c|c|c|c|c|}
\hline \multirow[t]{2}{*}{ Social Media Accounts } & \multicolumn{2}{|c|}{ \#IndonesiaBersamaJokowi } & \multicolumn{2}{|c|}{$\begin{array}{c}\text { \#Indonesia } \\
\text { ButuhPemimpin and \#Indonesia NeedLeader }\end{array}$} \\
\hline & Total & $\%$ & Total & $\%$ \\
\hline Jokowi supporters & 1128 & $70.5 \%$ & 19 & $0.8 \%$ \\
\hline Opponents of Jokowi & 12 & $0.8 \%$ & 1771 & $72.3 \%$ \\
\hline Not clear & 460 & $28.8 \%$ & 660 & $26.9 \%$ \\
\hline $\mathbf{N}$ & 1600 & $100.0 \%$ & 2450 & $100.0 \%$ \\
\hline
\end{tabular}

Chi square $=2787.69, p<0.000$

Source: obtained from primary data

or \#IndonesiaNeedLeader. Overall, if a differentiation test was carried out, there is a significant difference $(\mathrm{p}<0.001)$. This data indicates the occurrence of selective exposure. Social media users, who have been pro-Jokowi since the beginning, tend to choose positive information about Jokowi. The same thing applies to social media users who are antiJokowi, where they tend to choose information which criticizes Jokowi.

The second hypothesis to be tested in this study is that polarization occurs due to social media algorithm (filter bubble). Social media users become friends with people on social media who share the same political choice. This hypothesis was tested by identifying which text duplication of posts made by the users. Table
5 presents data regarding text duplication for each hashtag. The text duplication for hashtag \#IndonesiaBersamaJokowi is $66.3 \%$, while for hashtag \#IndonesiaButuhPemimpin and \#IndonesiaNeedLeader, the duplication rate is $65.5 \%$. From this data, it can be concluded that the majority of posts regarding Covid (both from social media accounts supporting or opposing Jokowi) has high text duplication. The contents of the post are relatively similar between one user and another. One user reposts a tweet from another user or slightly changes another user's tweet. This data proves the hypothesis of the filter bubble. Social media users live in a closed space with friends who have the same political opinions. This similarity is shown by how users post similar tweets to other users. 
Table 5.

Text Duplication

\begin{tabular}{lcccc}
\hline \multirow{2}{*}{ Duplication } & \multicolumn{2}{c}{ \#Indonesia BersamaJokowi } & \multicolumn{2}{c}{ \#Indonesia } \\
& \multicolumn{2}{c}{ Total } & ButuhPemimpin and \#Indonesia NeedLeader \\
\cline { 2 - 4 } & 1061 & $66.3 \%$ & 1606 & Total \\
\hline Text duplication & 311 & $19.4 \%$ & 388 & $15.8 \%$ \\
No text duplication & 228 & $14.3 \%$ & 456 & $18.6 \%$ \\
Not clear & 1600 & $100.0 \%$ & 2450 & $100.0 \%$ \\
$\mathbf{N}$ & &
\end{tabular}

Source: obtained from primary data

Table 6.

Cross Tabulation of Selected Posts and Hashtags Sentiments

\begin{tabular}{|c|c|c|c|c|}
\hline \multirow{2}{*}{ Hashtags Sentiments } & \multicolumn{2}{|c|}{ \#Indonesia BersamaJokowi } & \multicolumn{2}{|c|}{$\begin{array}{c}\text { \#Indonesia } \\
\text { ButuhPemimpin and \#Indonesia NeedLeader }\end{array}$} \\
\hline & Total & $\%$ & Total & $\%$ \\
\hline Positive & 1219 & $76.2 \%$ & 23 & $0.9 \%$ \\
\hline Negative & 71 & $4.4 \%$ & 2016 & $82.3 \%$ \\
\hline Unclear (not positive / negative) & 310 & $19.4 \%$ & 411 & $16.8 \%$ \\
\hline $\mathbf{N}$ & 1600 & $100.0 \%$ & 2450 & $100.0 \%$ \\
\hline
\end{tabular}

Chi square $=2929.14, p<0.000$

Source: obtained from primary data

Table 6 presents data on the relationship between post sentiment and the choice of hashtags used. This data shows that for the \#Indonesia BersamaJokowi posts, the majority $(76.2 \%)$ is positive and only $4.4 \%$ are negative posts. In the meantime, regarding posts with the hashtags \#IndonesiaButuhPemimpin and \#IndonesiaNeedLeader, the majority $(82.3 \%)$ is negative and only $0.9 \%$ of posts are positive. This data supports findings regarding political polarization. Those who use hashtags supporting Jokowi, not only connect with fellow supporters but also share contents about Jokowi in a positive tone. On the contrary, for the oppositions of Jokowi, they are connected with other users who are also anti-Jokowi and share messages (retweets, mentions or replies) and posts which criticize Jokowi.

\section{Discussion}

The research outcomes prove the political polarization. Social media users are divided into two major groups, namely pro-Jokowi and anti-Jokowi. Each group interacts with fellow users who share the same political choice and message content. These study outcomes confirm the findings of Lim (2017) regarding polarization in Indonesian politics. This research outcome shows that this polarization even leads to intense opposition to issues which are not politicized. The Covid-19 issue is a common threat and all citizens should work together to overcome this virus. The emergence of a crisis in the form of the Covid-19 pandemic is an opportunity for both pro and anti-Jokowi parties to give up their political choices and collectively face the crisis as a nation. This research shows how this political polarization occurs. Supporters and oppositions of Jokowi see the Covid-19 case differently. Those who support Jokowi view the Covid-19 management positively. Instead, those who oppose Jokowi tend to see the government policy negatively regardless of anything done by the Jokowi government.

This research shows that polarization is strengthened by social media algorithms (filter bubble) and selective exposure. The pro- 
Jokowi group has friends on social media who are fellow supporters of Jokowi. They also tend to choose positive information about Jokowi and ignore negative information. The same thing applies to the anti-Jokowi group. This condition creates a severe polarization between supporters and opposers of Jokowi on social media. The research also proves the validity of the selective exposure hypothesis in the Indonesian context. Users with certain political choices tend to receive the same information as their political choices, and ignore information from other political parties.

Another interesting finding from this study is how this polarization was sharpened by the use of hashtags. Each party (supporters and oppositions of Jokowi) uses hashtags to create solidarity and mobilization from each supporter. The research results support the argument presented by Yang (2016) on how hashtags are used by social media users to create imaginative communities. Hashtags are identity makers, where each group uses different hashtags to assert the identity of different political choices. Hashtag uses emotional language to attract support from other social media users to get involved in supporting or opposing Jokowi. This condition will lead to an increasing political polarization.

This study illustrates the political polarization on social media. The outcomes of this study indicate an alarming condition, at least among Indonesian netizens. The research explains how polarization has taken place since the General Election (Election) in 2014 and continued to the 2016 Jakarta Gubernatorial Election and 2019 Election. This polarization does not show any signs of stopping. Rather, it indeed increases. As illustrated in the outcomes of this study, regarding any issues related to non-political topics (Covid-19 issue), the social media users remain segregated based on political choices. Does this polarization on social media illustrate the polarization in the real world? This study does not answer this question. Further research is required to answer the question of political polarization in the real world or other research to see how much the impact of polarization on social media on the political polarization in the real world.

\section{Conclusion}

This research had two objectives. First, discussing political polarization on social media in the case of a discussion about Covid-19. The results showed that political polarization occurred. Social media users who are pro and anti-Joko Widodo are divided into two separate groups.

Second, the study examines the hypothesis of the bubble filter and selective exposure in the Indonesian context. The results showed both hypotheses were proven. Social media users who are pro-Jokowi choose the pro-Jokowi hashtag (\#Indonesia BersamaJokowi), while anti-Jokowi users prefer to use the anti-Jokowi hashtag \#IndonesiaButuhPemimpin and \#IndonesiaNeedLeader.

\section{References}

Agarwal, N., \& Liu, H. (2009). Modeling and data mining in blogosphere. In R. Grossman (ed), Synthesis lectures on data mining and knowledge discovery (pp.1109). California: Morgan \& Claypool Publishers. https://doi.org/10.2200/ S00213ED1V01Y200907DMK001.

Bakshy, E. , Messing, S., \& Adamic, L.A. (2015). Exposure to ideologically diverse news and opinion on facebook. Science Magazine, 348(6239), 1130-1132. https:// doi.org/10.1126/science.aaa1160.

Barisione, M., Michailidou, A., \& Airoldi, M. (2017). Understanding a digital movement of opinion: The case of \#RefugeesWelcome. Information, Communication \& Society, 22

(8), 1145-1164. https://doi.org/10.1080/13 69118X.2017.1410204

Barisione, M., \& Ceron, A. (2017). A digital movement of opinion?: Contesting 
austerity through social media. In Barisione, M. \& Michailidou, M. (Eds.), Social media and European politics: Rethinking power and legitimacy in the digital era (pp. 89-118). Basingstoke: Palgrave Macmillan.

Bennett, W. L. \& Iyengar, S. (2008). A new era of minimal effects? The changing foundations of political communication. Journal of Communication, 58 (4) 707 731. https://doi.org/10.1111/j.14602466.2008.00410.x.

Bishop, B. (2008) The big sort: Why the clustering of like-minded merica is tearing us apart. New York: Mariner Books.

Borgatti, S.P., Everett, M. G., \& Johnson, J.C. (2013). Analyzing social network. Thousand Oaks, CA: Sage Publications.

Borgesius, F.J.Z, Trilling, D., \& Moller, J. (2016). Should we worry about filter bubbles? Internet Policy Review, 5(1), 1-16. https:// doi.org/10.14763/2016.1.401.

Bozdag, E., \& van den Hoven, J. (2015). Breaking the filter bubble: Democracy and design. Ethics and Information Technology, 17, 249-265. https://doi.org/10.1007/ s10676-015-9380-y.

Bruns, A., \& Burgess, J. (2012). Researching news discussion on twitter: New methodologies. Journalism Studies, 13(56), 801-814. https://doi.org/10.1080/1461 670X.2012.664428.

Del Vicario, M., Zollo, F., \& Caldarelli, G. (2017). Mapping social dynamics on facebook: The brexit debate. Social Networks, 50, 6-16. https://doi. org/10.1016/j.socnet.2017.02.002.

Dylko, I., Dolgov, I., \& Hoffman, W. (2017). The dark side of technology: An experimental investigation of the influence of customizability technology on online political selective exposure. Computer in Human Behavior, 73, 181-190. https://doi. org/10.1016/j.chb.2017.03.031.
Frey, D. (1986). Recent research on selective exposure to information. In Liao, Q.V., Fu, W., \& Mackay, W.E. (Eds.) Beyond the filter bubble: Interactive effects of perceived threat and topic involvement on selective exposure to information (pp. 2359-2368). Changing Perspectives Conference, Paris, France, 27 April-02 May 2013,. New York, NY, USA: ACM.

Gil de Zuniga, H., \& Diehl, T. (2017). Citizenship, social media, and big data: Current and future research in social sciences. Social Science Computer Review, 35(1), 3-9. https:// doi.org/10.1177/0894439315619589.

Gil de Zuniga, H., Weeks, B., \& Arde'vol-Abreu, A. (2017). Effects of the news-finds-me perception in communication: social media use implications for news seeking and learning about politics. Journal of Computer-Mediated Communication, 22 (3), 105-123. https://doi.org/10.1111/ jcc4.12185.

Golbeck, J. (2013). Analyzing the social web. Waltham, MA: Morgan Kauffman.

Hexmoor, H. (2015). Computational network science: An Algorithmic approach. Waltham, MA: Morgan Kaufmann.

Iyengar, S., \& Hahn, K.S. (2009). Red media, blue media: Evidence of ideological selectivity in media use. Journal of Communication, 59(1), 19-39. https://doi. org/10.1111/j.1460-2466.2008.01402.x.

Iyengar, S., Sood, G., \& Lelkes, Y. (2012). Affect, not ideology: A social identity perspective on polarization. Public Opinion Quarterly, 76(3), 405-431. https://doi.org/10.1093/ poq/nfs038.

Jacobson, S., Myung, E., \& Johnson, S.L. (2016). Open media or echo chamber: The use of links in audience discussions on the facebook pages of partisan news organizations. Information, Communication and Society, 19(7), 875-891. https://doi.org /10.1080/1369118X.2015.1064461 
Kull, S., Ramsay, C., \& Lewis, E. (2004). Misperceptions, the media, and the iraq war. Political Science Quarterly, 118(4), 569-598. https://doi.org/10.1002/j.1538165X.2003.tb00406.x.

Lim, M. (2017). Freedom to hate: Social media, algorithmic enclaves, and the rise of tribal nationalism in Indonesia. Critical Asian Studies, 49 (3), 411-427. https://doi.org/10 .1080/14672715.2017.1341188.

Maffesoli, M. (2016). From society to tribal communities (translated from the French by Rob Atkins). The Sociological Review, 64(4), 739-747. https://doi. org/10.1111/1467-954X.12434/

Marozzo, F. \& Bessi, A. (2017). Analyzing polarization of social media users and news sites during political campaigns. Social Network Analysis and Mining, 8 (1). https://doi.org/10.1007/s13278-017-0479-5.

Negroponte, N. (1996). Being digital. London: Hodder \& Stoughton

Pariser, E. (2011). The Filter bubble: What the internet is hiding from you. New York: Penguin Group.

Rader, E., \& Gray, R. (2015) Understanding user believes about algorithmic curation in the facebook news feed. In Begole, B. \& Kim J, (Eds,) Proceedings of the $33 \mathrm{rd}$ Annual ACM Conference on Human Factors in Computing
Systems (pp. 173-182). Seoul, Republic of Korea, 18-23 April 2015,. New York, NY, USA: ACM.

Rosyadi, M. S., \& Eriyanto. (2019). The influence of the social media recommendation system against polarization in the views of user politics: Experiments on social media newsfeed on social media users. Proceedings of the 1st Sampoerna University-AFBE International Conference, SU-AFBE 2018, 6-7 December 2018, Jakarta Indonesia. https://doi. org/10.4108/eai.6-12-2018.2286272

Stroud, N.J. (2008). Media use and political predispositions: Revisiting the concept of selective exposure. Political Behaviour, 30, 341-366. https://doi.org/10.1007/s11109007-9050-9.

Stroud, N.J. (2010) Polarization and partisan selective exposure. Journal of Communication, 60(3), 556-576. https:// doi.org/10.1111/j.1460-2466.2010.01497.x.

West, R., \& Turner, L. (2018). Introducing communication theory: Analysis and application. 4th Edition. New York, McGraw-Hill.

Yang, G. (2016). Narrative agency in hashtag activism: The case of \#BlackLivesMatter. Media and Communication, 4 (4), pp. 13-17. https://doi.org/10.17645/mac.v4i4.692. 